\title{
Public Service Innovation Through Suroboyo Bus to Improve the Accessibility of Public Transportation
}

\author{
Tjitjik Rahaju ${ }^{1}$, Galih Wahyu Pradana $^{2}$, Deby Febriyan Eprilianto ${ }^{3}$ \\ \{tjitjikrahaju@unesa.ac.id¹, galihpradana@unesa.ac.id², debyeprilianto@unesa.ac.id $\left.{ }^{3}\right\}$ \\ Department of Public Administration Faculty of Social Science and Law Universitas \\ Negeri Surabaya, Surabaya Indonesia ${ }^{123}$ \\ Department of Public Administration Faculty of Social Science and Law Universitas \\ Negeri Surabaya, Surabaya Indonesia ${ }^{2}$ \\ Department of Public Administration Faculty of Social Science and Law Universitas \\ Negeri Surabaya, Surabaya Indonesia ${ }^{3}$
}

\begin{abstract}
Transportation accessibility is an important issue related to the existence of transportation in urban areas which is less attractive to the public because it is often considered inappropriate. The Surabaya City Department of Transportation developed Suroboyo Bus as an alternative to solve the problems of public transportation. What's interesting is Suroboyo Bus is not only safe, comfortable, and can be accessed online. However, the payment innovation paid for plastic waste. So that the spirit of presenting environmentally friendly public transportation becomes an innovation that deserves to be appreciated. The article was developed with a quantitative approach whose data was collected through a questionnaire from users of the Suroboyo Bus route Unesa-ITS. The data were analyzed by using a linear regression test on the service quality variables of Suroboyo Bus and the accessibility variables. The results showed that there is a relationship between the variable quality of public transportation services to the Suroboyo Bus accessibility.
\end{abstract}

Keywords: Public Service, Innovation, Suroboyo Bus, Transportation Accessibility

\section{Introduction}

Public transport is an essential component of a country's development[1] including in its cities[2]. Unfortunately, the condition of public transportation is often very poorly accessible[3]. This accessibility has always been an important issue in public transportation discussions[4]. The importance of accessibility of public transportation is often associated with the low interest of the public in utilizing public transportation. Low access to public transportation is often associated with the presence of transportation in many cities in Indonesia, which are generally not in a feasible condition. How to plan effective public transportation is a difficult process. Planning of transportation operations and their execution in an efficient way is a complex process requiring coordination of different activities[5]. There are a lot of factors which affect determining the route of mass vehicles, for example, the terminals, kind of vehicles, (as per capacity, speed, and technical quality), and the kind of route lines network (radical, chessshaped, diametrical networks, etc)[6] and especially if it is close to housing, it can also increase 
the value of the house[7]. Authorities are expected to provide citizens with an effective, accessible, secure, and equitable transportation service[1]. The condition of public transportation with low accessibility is an interesting part to be studied more deeply. This is mainly related to how city managers must respond in the form of policies that can provide transportation services that are not only good but also of high quality. This issue is particularly important and controversial at a time when the authority of the public planner is being challenged and transformed by institutional reforms and new governance dynamics[8]. It is also important to collaborate with various parties[9]. As a big city, public transportation problems can also be found easily in Surabaya[10] Even for vulnerable groups it becomes difficult to access, such as parents, pregnant women, and people with disabilities[11]. The conditions of transportation facilities that are uncomfortable and many of them do not meet the eligibility standards are the reason Surabaya people are reluctant to use public transportation[12]. The Surabaya City Department of Transportation in 2007 made an effort to provide public transportation for students in the city of Surabaya. This student bus can be accessed by students for free[13]. Department of Transportation continues to develop innovation through the Suroboyo Bus which is intended for the people of Surabaya in 2018[14]. The new transportation in the form of the Suroboyo Bus is intended to support community activities[10]. According to the initial interview with the Surabaya City Transportation Agency, the Suroboyo Bus was intended as a solution to the problem of public transportation in Surabaya which is often called inadequate. This article will focus on the public response in accessing Suroboyo Bus.

\section{Methodology}

This type of research is quantitative with 2 variables, namely accessibility of public transportation and quality of service. The research wanted to find out how the Surabaya community's perceptions of the quality of services provided by the Transportation Agency by presenting the Suroboyo Bus innovation and the level of accessibility of the Surabaya community in using it as a public transportation option. The research was conducted for the Unesa - ITS campus route, which every day has 200 passengers on average. The sample was taken by random sampling as many as 65 passengers by accidental sampling. Data collection was carried out using a questionnaire and processed with the help of SPSS version 20.

\section{$3 \quad$ Finding and Discussion}

\subsection{Suroboyo Bus Innovation}

Suroboyo Bus is public transportation provided by the Surabaya city government through the Department of Transportation. Suroboyo Bus is related to the service sector which is the duty and responsibility of the government and local governments in its provision, as regulated by law. In the Republic of Indonesia Law 22/2009 on Traffic and Road Transportation, it is stated in Article 138 that public transportation is organized to meet the needs of safe, secure, and affordable transportation. Meanwhile, Article 139 paragraph (3) states that the district/city government is obliged to guarantee the availability of public transportation for the transportation of people and/or goods within the district/city. Referring to the regulation of this article, public service providers, Department of Transportation are required to continue to innovate by 
providing public transportation that meets minimum service standards, namely security, safety, comfort, affordability, equality, and order. From the observation, it is found that the Suroboyo Bus is physically capable of appearing as a modern means of transportation that is designed with ergonomics, elegance, beauty, and modernity. Suroboyo Bus's comfort is realized by a comfortable and fitting seating design. Thus, passengers who take long routes, let alone transit, still feel comfortable and not tired. The music accompaniment is played to make passengers feel calm and enjoy the trip. The number of passengers is limited so that passengers feel comfortable. Innovation is also shown by caring for vulnerable groups, such as the elderly, pregnant women, and people with disabilities. Seat facilities are provided specifically for this group. Technological innovation is realized by installing CCTV cameras, to prevent criminal acts and installation of mobile phone battery charging. The separation of seats for men and women, except for children, is intended to reduce the occurrence of sexual harassment. The bus is designed to make it easier for passengers to get on and off. The bus is designed to make it easier for passengers to get on and off. Also equipped with automatic doors controlled by the driver. The conditions of comfort and safety as shown in Suroboyo Bus may never have been found in public transportation in general. The innovation developed by the Surabaya City Transportation Agency is not only related to physical appearance. But also innovations related to passenger payment mechanisms. To be able to access this bus, passengers pay with plastic waste. Plastic waste is carried and exchanged directly for bus tickets on the Suroboyo Bus crew. Or users can use the card after previously exchanging plastic waste at the exchange at Bungurasih Terminal, Mayjen Sungkono Park Ride, and Jembatan Merah. The new idea in the payment mechanism for waste-based public transportation positions public service providers who have great attention to environmental sustainability issues. So that in terms of the public's way of accessing services, it becomes an alternative breakthrough in solving environmental problems. Regarding the payment mechanism for waste, the Department of Transportation in collaboration with DKRTH in Surabaya refers to its function in optimizing the utilization and selection of waste. Besides, it also reduces plastic waste in the city of Surabaya.

The use of the Suroboyo Bus application also makes it easier for the people of Surabaya to access it. Through this application, the public can more easily find out where the Suroboyo Bus is. So for service users, it is easier to estimate the time to reach the bus stop with the closest bus position. The menus displayed in the application are also easy to understand. The following is a menu view of Suroboyo Bus.

\subsection{Characteristics of Accessors of Suroboyo Bus}

The target users of the Suroboyo Bus service are all people who need services or who mobilize to and from the various routes provided by the transportation agency. The results of this study indicate that the Suroboyo Bus service users come of various ages. However, those who dominate are users aged 15-24, namely $69.2 \%$. This means that more than half of the service users are from this age group, as in the following diagram : 


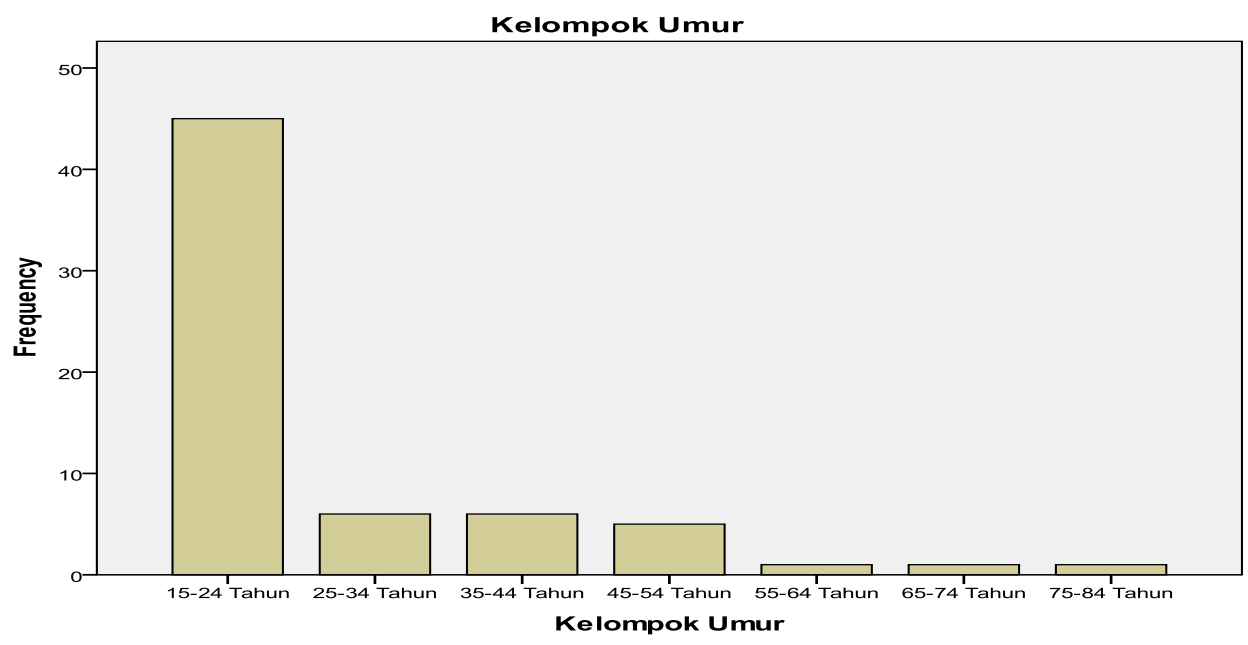

Meanwhile, the description of the Suroboyo Bus operators, if seen from their gender, is more dominated by women, $73.8 \%$, while men $26.2 \%$. Display the diagram below to further clarify the view of the Suroboyo Bus accessors from gender.

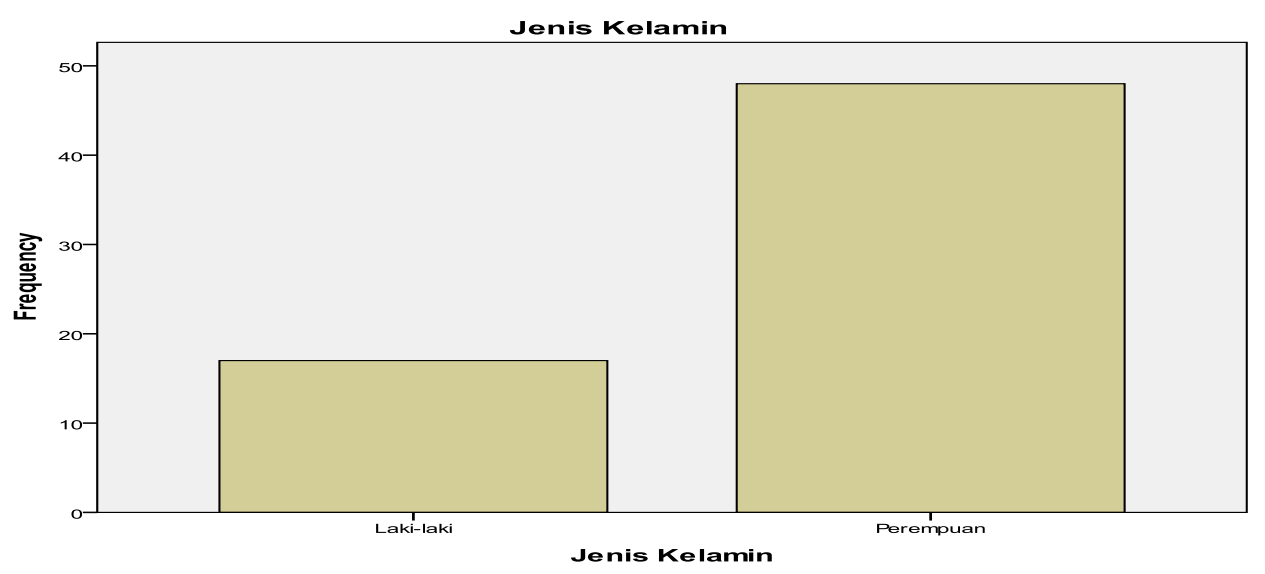

Thus, the seating capacity provided is less than the number of passengers. Given the seating capacity provided for women is 12 seats. At the same time, these findings become material for evaluation to consider the additional capacity for female passengers. The people who use Suroboyo Bus a lot according to the results of the research are college students. The number who access the Suroboyo Bus on the Unesa-ITS route is $53.5 \%$. For workers or employees, the existence of Suroboyo Bus also helps them, as evidenced by $26.2 \%$ of accesses are workers, others are students, housewives. 


\subsection{Accessibility of Suroboyo Bus}

The identification of indicators that are seen as influencing the level of accessibility of Suroboyo Bus is also a reflection of this article. The results showed that the user response to the existence of transportation innovations developed by the Department of Transportation was as follows:

\begin{tabular}{lrrrrr}
\hline Indicator & Disagree & Disagree less & Agree & Strongly agree & Total \\
\hline not long waiting for the & 0 & $32.31 \%$ & $47.69 \%$ & $20 \%$ & $100.00 \%$ \\
bus & $6.15 \%$ & $32.31 \%$ & $32.31 \%$ & $29.23 \%$ & $100.00 \%$ \\
bus shelter not far away & 0 & $1.54 \%$ & $29.23 \%$ & $69.23 \%$ & $100.00 \%$ \\
comfortable & 0 & $1.54 \%$ & $15.38 \%$ & $83.08 \%$ & $100.00 \%$ \\
clean & & & & & \\
enough time to change & 0 & $21.54 \%$ & $53.85 \%$ & $24.61 \%$ & $100.00 \%$ \\
routes & 0 & $4.61 \%$ & $41.54 \%$ & $53.85 \%$ & $100.00 \%$ \\
good seating design & 0 & $10.77 \%$ & $40 \%$ & $49.23 \%$ & $100.00 \%$ \\
comfortable music & $9.23 \%$ & $18.46 \%$ & $23.08 \%$ & $49.23 \%$ & $100.00 \%$ \\
ease of going up and down & 0 & $15.39 \%$ & $58.46 \%$ & $26.15 \%$ & $100.00 \%$ \\
large capacity & $6.15 \%$ & $4.62 \%$ & $30.77 \%$ & $58.46 \%$ & $100.00 \%$ \\
ease of payment & $4.62 \%$ & $4.62 \%$ & $21.54 \%$ & $69.22 \%$ & $100.00 \%$ \\
using plastic waste & & & & & \\
\hline
\end{tabular}

The table shows that no Suroboyo Bus service users perceive it negatively. Or it means that you strongly disagree with the presence of Suroboyo Bus and the innovations it displays. In fact, almost all users agree even on several indicators such as comfortable, clean, good seating design, comfortable music, ease of payment, and using plastic waste, users strongly agree that the Suroboyo Bus innovation is indeed worthy of access. Even so, there are still users who feel that the Suroboyo Bus innovation still needs to be improved. This can be seen from the indicator that the bus stops are still far away according to the user. This means that there are still people who feel that the Suroboyo Bus stop is still considered far away from being accessed by the public. Likewise, there are still users who find it difficult when they have to get on and off the Suroboyo Bus. This includes a payment mechanism using plastic waste for some service users which is considered difficult to implement. However, through further search, this difficulty is usually encountered by new users or people outside the city. So it is possible that the previous information has not been received.

\subsection{Improving the Quality of Transportation Services}

Surabaya City Transportation Agency continues to strive to create good service. The existence of Suroboyo Bus is also intended to fulfill this. regarding this reason, this study explores the perceptions of service users with the objectives that should be achieved with the quality of services provided by Suroboyo Bus. The results showed that almost all of the viewers strongly agreed or agreed to this, as presented in the following table: 


\begin{tabular}{lcccc}
\hline Indikator & Disagree less & Agree & Strongly agree & Total \\
\hline $\begin{array}{l}\text { Suroboyo buses provide safe and } \\
\text { comfortable public transportation }\end{array}$ & $1.54 \%$ & $20 \%$ & $78.46 \%$ & \\
& & & & $100.00 \%$ \\
$\begin{array}{l}\text { Suroboyo Bus provides a choice of } \\
\text { public transportation }\end{array}$ & $1.54 \%$ & $49.23 \%$ & $49.23 \%$ & $100.00 \%$ \\
$\begin{array}{l}\text { Suroboyo Bus Crew has a passion } \\
\text { for carrying out their duties }\end{array}$ & $6.15 \%$ & $46.15 \%$ & $47.70 \%$ & $100.00 \%$ \\
\hline
\end{tabular}

In general, the results of this study show a positive value for the existence of Suroboyo Bus. However, there were still some accessors who stated they did not agree with the service improvements that had been carried out. This is revealed from the findings of data on the question indicator of the friendliness of the Suroboyo Bus Crew in greeting passengers. There are still $1.54 \%$ of viewers who think there are still unfriendly crews. Likewise, for the driver's caution in driving the Suroboyo Bus, it was found that $3.08 \%$ of the accessors stated that there were still drivers who were not careful. Including the opportunity given by the driver to drop off and pick up passengers, it was found that there were $1.54 \%$ of accessors who stated that the driver had not given them enough time.

\subsection{The effect of improving the quality of public transport services through the Suroboyo Bus Innovation on Suroboyo accessibility}

To see how much influence the variable improving service quality has on the accessibility of Suroboyo Bus, a simple linear regression test was carried out. The variable for improving the quality of public transportation services through the Suroboyo Innovation is the independent variable while the Suroboyo Bus accessibility variable is the dependent variable. The test results using the SPPS 20 statistic obtained the results of the calculation of the correlation of 2 variables, which indicates that the relationship between variables can be seen from the magnitude of the Pearson Correlation and the significance of its value. The calculation results show that there is a correlation of 0.564 , which means that there is a relationship between the two variables.

\section{Conclusion}

Based on the test results, the following conclusions were drawn:

1. This study concludes that the Surabaya City Transportation Agency has developed an innovation for the procurement of public transportation.

2. The innovation made is by holding a Suroboyo Bus. The concept of innovation is carried out to increase public access to public transportation

3. From the results of statistical testing with simple linear regression, it is concluded that; 
a. There is a relationship between the Suroboyo Bus Accessibility Variable and the Variable Quality of Public Transportation Services, which is indicated by a Pearson Correlation value of 0.564 .

b. Meanwhile, the significance value of 0.000 also proves that this relationship shows a close relationship. Variable Quality of Public Transportation Services with Variable Accessibility of Suroboyo Bus.

\section{References}

[1] L Delgado M J, Miguel Angel Sanchez de Lara, and Vera Gelashvili .Explanatory Factors for Public Transportation Financing Needs in Spain. Journal of Advanced Transportation Volume 2019;1-12

[2] Jie Wu, Liang Cheng, Sensen Chu, Nan Xia \& Manchun Li. A green view index for urban transportation: How much greenery do we view while moving around in cities? International Journal of Sustainable Transportation.2019;1-18

[3] Book: Author AA. Title of book. Edition [if not first]. Place of publication: Publisher; Year of publication. Pagination.

[4] Zsuzsanna Olofsson, Lena Hiselius \& András Várhelyi.Development of a Tool to Assess Urban Transport Sustainability - the Case of Swedish Cities, International Journal of Sustainable Transportation.2015;8318,December.

[5] Emrah Demir, Martin Hrušovský, Werner Jammernegg \& Tom Van Woensel .Green intermodal freight transportation: bi-objective modelling and analysis, International Journal of Production Research.2019;7543 May.

[6] Hassan Ziari , Mahmud R. Keymanesh \& Mohammad M. Khabiri. Locating stations of public transportation vehicles for improving transit accessibility.2016. Transport.2016; 22:2, 99-104.

[7] Erin A. Hopkins. The influence of public transportation on housing values. International Journal of Sustainable Development \& World Ecology.2017;1-10.

[8] Enza Lissandrello, Robert Hrelja, Aud Tennøy \& Tim Richardson.Three performativities of innovation in public transport planning, International Planning.International Planning Study.2016;3475.

[9] Zhenhua Chen, Nobuhiko Daito \& Jonathan L. Gifford. Data Review of Transportation Infrastructure Public-Private Partnership: A Meta-Analysis.Transport Reviews.2015;1-25.

[10] Siti Aminah. Transportasi Publik dan AksesibilitasMasyarakat Perkotaan available at http://www.journal.unair.ac.id/filerPDF/Transportasi\%20Publik\%20dan\%20Aksesibi litas.pdf

[11] Sugi Rahayu, Utami Dewi, Marita Ahdiyana. Pelayanan Publik Bidang Transportasi bagi Difabel di Daerah Istimewa Yogyakarta. Jurnal Ilmu-ilmu Sosial. 2013;September 2013, Vol. 10, No. 2 , 108 - 119

[12] Kurniawan, Anugrah Ari, Indah Prabawati. Implementasi Suroboyo Bus di Dinas Perhubungan Kota Surabaya. Publika.2018; Vol 6:9.

[13] Arini Sulistyowati, Imam Muazansyah. Optimalisasi Pengelolaan dan Pelayanan Transportasi Umum (Studi pada "Suroboyo Bus" di Surabaya). Collaborative Government to Strenghten Local and Global Competitiveness.Proceedings IAPA Annual Conference 2018; 11-12 Ocotober 2018; Universitas Muhammadiyah 
Palangkaraya . Palangka Raya. Publisher:Indonesian Association for Public Administration;2019.152-165.

[14] Prananda Kamaluddin Rafif. Analisis Statistik Kepuasan Pengguna Suroboyo Bus dengan Menggunakan Metode Customer Satisfaction Index, dan Analisis Kesenjangan. 2019 available at http://repository.unair.ac.id/id/eprint/81398 